\title{
The Gorgon gas development and its environmental commitments
}

\author{
Russell Lagdon and Dorian Moro
}

\author{
Chevron Australia Pty Ltd, 250 St Georges Terrace, Perth, Western Australia 6000, Australia. \\ Email: rdla@chevron.com
}

\begin{abstract}
Chevron has made an important contribution to our knowledge and understanding of the Barrow Island flora and fauna, and to the Australian economy. This knowledge has been primarily founded from the investigations and commitments of joint venture partners associated with the environmental impact assessment for the Gorgon Gas Development. The Gorgon Gas Development is one of the world's largest natural gas projects and the largest single natural gas project in Australia's history. Development has been balanced between energy needs and environmental management. Through plans, procedures, programs and research, Chevron Australia and its joint venture participants have established a benchmark for environmental management of this important island reserve. Furthermore, the Gorgon Joint Ventures have contributed to one of the largest biodiversity offset and Net Conservation Benefit programs in Western Australia.
\end{abstract}

KEYWORDS: Barrow Island, Chevron, Environmental Impact Assessment, Gorgon, island

Chevron Australia, firstly as joint venture participant in West Australian Petroleum (WAPET) and later as operator in its own right, has had a nearly half a century relationship with Barrow Island. While oil exploration permits were granted over Barrow Island and surrounding waters after World War II, it wasn't until after the lifting of access restrictions following the British atomic tests on the nearby Montebello Islands in 1963 that investigation of Barrow Island oil commenced in earnest.

The first well was drilled in 1964 and it was successful. Following that first well, a period of substantive activity was undertaken on Barrow Island to develop the oilfield and associated infrastructure culminating in the first shipment of Barrow Island crude in 1967.

At this time there was limited regulatory oversight and little guiding environmental regulation. However, the eminent naturalist Harry Butler visited Barrow Island several times in 1964 and 1965 while making state-wide collections on behalf of the WA Museum and the American Museum of Natural History. Through these early visits, Dr Butler developed a strong and lasting relationship with the company and was able to make recommendations on conservation for the company to enact.

A key recommendation of Dr Butler was the establishment of a quarantine program to prevent the introduction of cats, rats, mice and weeds. Dr Butler also recommended a program of no pets, no firearms, no interference with the animals, and restoration of disturbed areas. In 1970 WAPET asked Dr Butler to become the Conservation Consultant to the company, to visit Barrow Island regularly, and to provide advice as to how to best keep the island as they first found it. This resulted in the first conservation management program for Barrow Island.

Since those early years the environmental program on Barrow Island has continued to develop and mature in the light of experience gained on the island and the drive to continually improve the company's performance.

Chevron Australia has further developed and implemented the environmental management program on Barrow Island in alignment with five key strategies:

Prevent the introduction of non indigenous species through an effective quarantine management system;

Engage and involve the workforce in the environmental management of the island such that they feel pride and have ownership;

Progressively and actively rehabilitate areas that have been disturbed;

Adapt the environmental management program 
based on experience gained and outcomes achieved; and

Take measures to ensure the prevention of incidents.

In late 2001 Chevron Australia commenced discussion with the government about the potential to site the Gorgon Project on Barrow Island. The proposal was to pipe the gas from the offshore gas fields to Barrow Island, where it would be processed to Liquefied Natural Gas (LNG) and then shipped to buyers in the Asia Pacific region.

To assist the consideration of the proposal by government and the public, Chevron Australia developed and published an Environmental Social and Economic Review (ESER) of the Project (Chevron Australia 2003). Key aspects considered in the ESER included alternative sites in the Pilbara, site selection on Barrow Island, greenhouse gas management and quarantine. In 2003 the Western Australian Government proclaimed the Barrow Island Act and Chevron Australia signed a State Agreement. This allowed the commencement of the formal Environmental Impact Assessment of the Project under the Environmental Protection Act (Chevron Australia 2005, 2006), and later a revised and expanded proposal (Chevron Australia 2008). The Project involves the construction of a threetrain, 15 million tonnes per year LNG facility and a 300 TJ per day domestic gas plant. Gorgon LNG will be off-loaded via a $4 \mathrm{~km}$ long loading jetty for transport to international markets. Carbon dioxide from the Gorgon reservoir gas will be removed and injected deep (2000 - 2500m) below Barrow Island. The domestic gas will be piped to the Western Australian mainland. The domestic gas component of the Project will increase domestic gas supplies into WA by about one third. First LNG production is scheduled for late-2015.

Gas from the Gorgon field, and the nearby deepwater gasfield of Jansz-Io, will be produced from sub-sea wells and transported to Barrow Island via pipelines for processing.

After a lengthy and detailed assessment process, final Federal and State Government approvals for the Gorgon Project were given, first in 2007, and later in 2009 to support a revised and expanded proposal (Government of Western Australia 2007, 2009; Commonwealth Government of Australia 2007, 2009). The approval conditions, plus the requirements of the State Agreement signed in 2003, define the required environmental performance. Pertinent requirements on the development were:

Restrictions on taking tenure over undisturbed vegetation on Barrow Island for the Gorgon Project to 300 ha out of 23,400 ha;

Funding of the permanent presence of the
Western Australian Department of Environment and Conservation on the island;

Funding for Net Conservation Benefits to add to or improve biodiversity conservation values targeting, where possible, the biodiversity conservation values affected or occurring in similar bioregions to Barrow Island in Western Australia

The funding of a North West Shelf Flatback Turtle Conservation Program over a 60 year period, which includes activities to survey, monitor and research flatback turtle populations in the region; and

The establishment of three independent expert panels to advise the WA Minister for Environment and Chevron Australia. The panels provide advice on dredging, quarantine, and flatback turtles.

In addition, to drive environmental protection and conservation outcomes, more than 30 Environment Management Plans have been developed by Chevron Australia and approved by the WA State and Commonwealth Governments (see http:// www.chevronaustralia.com/ourbusinesses/ gorgon/environmentalresponsibility / environmentalapprovals.aspx, accessed November 2012). These plans, processes and systems have leveraged the collective environmental knowledge of nearly 50 years of oilfield operation on Barrow Island. This suite of protection measures is now built into every aspect of the construction and operation plans for the Gorgon Project.

An important aspect of protection measures is to monitor for impact on the environment, achieved though a government requirement to design monitoring programs (including quarantine surveillance for invertebrates), with the ability to detect, at a statistical power of 0.8 or greater, or an alternative statistical power as determined by the Minister for the Environment in Western Australia, changes or impacts on key ecological elements on Barrow Island.

The Gorgon Gas Development is one of the world's largest natural gas projects and the largest single natural gas project in Australia's history. Through plans, procedures, programs and research, Chevron Australia and its joint venture participants have established a benchmark for environmental management of this important island reserve.

The Gorgon Gas Development is operated by Chevron Australia Pty Ltd (Chevron Australia), an Australian subsidiary of Chevron Corporation, and is owned by a joint venture comprising Chevron Australia (approximately 47.3 per cent) and Australian subsidiaries of ExxonMobil (25 per cent), Shell (25 per cent), Osaka Gas (1.25 per cent), Tokyo Gas (one per cent) and Chubu Electric Company (0.417 per cent). 


\section{REFERENCES}

Chevron Australia (2003). Environmental, Social and Economic Review of the gorgon Gas Development on Barrow Island. Chevron Australia, Perth, Australia.

Chevron Australia (2005). Draft Gorgon Environmental Impact Statement/Environmental Review and Management Programme for the Proposed Gorgon Development. Chevron Australia, Perth, Australia.

Chevron Australia (2006). Final Environmental Impact Statement/Environmental Review and Management Programme for the Gorgon Gas Development. Chevron Australia, Perth, Australia.

Chevron Australia (2008). Gorgon Gas Development Revised and Expanded Proposal Public Environmental Review. Chevron Australia, Perth, Western Australia.

Commonwealth Government of Australia (2007). Approval
- Gorgon Gas Development (EPBC Reference: 2003/1294), 3 October 2007. Canberra, Australian Capital Territory.

Commonwealth Government of Australia (2009). Approval - Gorgon Gas Development (EPBC Reference: 2008/4178), 26 August 2009. Canberra, Australian Capital Territory.

Government of Western Australia (2007). Statement that a Proposal may be Implemented - Gorgon Gas Development: Barrow Island Nature Reserve (Ministerial Statement No. 748), 6 September 2007. Perth, Western Australia.

Government of Western Australia (2009). Statement that a Proposal may be Implemented - Gorgon Gas Development Revised and Expanded Proposal: Barrow Island Nature Reserve (Ministerial Statement No. 800), 10 August 2009. Perth, Western Australia.

MANUSCRIPT RECEIVED 13 DECEMBER 2012; ACCEPTED 20 MARCH 2013. 